DOE/NV/11508-08

UC-703

\title{
EVALUATION OF THE RADIONUCLIDE TRACER TEST CONDUCTED AT THE PROJECT GNOME UNDERGROUND NUCLEAR TEST SITE, NEW MEXICO
}

\author{
prepared by \\ Greg Pohll and Karl Pohlmann
}

submitted to

Nevada Operations Office

U.S. Department of Energy

AUGUST 1996

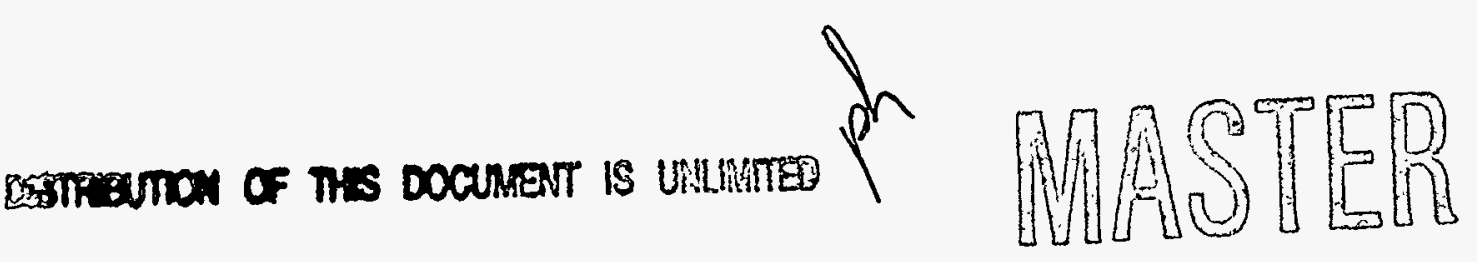

Publication \#45141 


\section{DISCLAMIER}

Portions of this document may be illegible in electronic image products images are produced from the best available original document. 
This report was prepared as an account of work sponsored by the United States Government. Neither the United States nor the United States Department of Energy, nor any of their employees, makes any warranty, express or implied, or assumes any legal liability or responsibility for the accuracy, completeness or usefulness of any information, apparatus, product or process disclosed, or represents that its use would not infringe privately owned rights. Reference herein to any specific commercial product, process. or service by trade name, mark, manufacturer, or otherwise, does not necessarily constitute or imply its endorsement, recommendation, or favoring by the United States Government or any agency thereof. The views and opinions of authors expressed herein do not necessarily state or reflect those of the United States Government or any agency thereof.

This report has been reproduced directly from the best available copy.

Available to DOE and DOE contractors from the Office of Scientific and Technical Information, P.O. Box 62, Oak Ridge, TN 37831; prices available from (423) 576-8401.

Available to the public from the National Technical Information Service, U.S. Department of Commerce, 5285 Port Royal Rd., Springfield, VA 22161. 


\title{
EVALUATION OF THE RADIONUCLIDE TRACER TEST CONDUCTED AT THE PROJECT GNOME UNDERGROUND NUCLEAR TEST SITE, NEW MEXICO
}

\author{
prepared by \\ Greg Pohll and Karl Pohlmann \\ Water Resources Center \\ Desert Research Institute \\ Publication No. 45141 \\ submitted to \\ Nevada Operations Office \\ U.S. Department of Energy \\ Las Vegas, Nevada
}

University and Community College System of Nevada

August 1996

The work upon which this report is based was supported by the U.S. Department of Energy under Contract \#DE-AC08-95NV11508. 


\section{CONTENTS}

EXECUTIVE SUMMARY $\ldots \ldots \ldots \ldots \ldots \ldots \ldots \ldots \ldots \ldots \ldots \ldots \ldots \ldots \ldots \ldots$

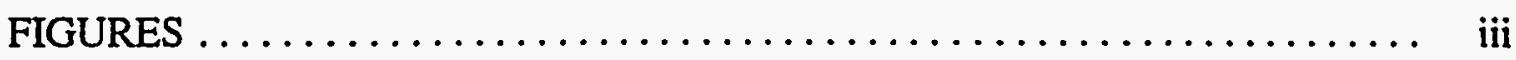

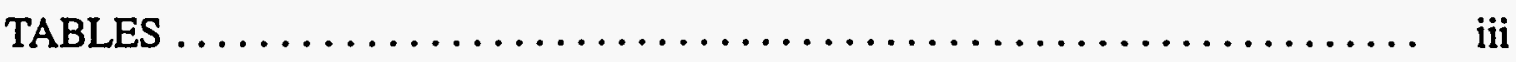

INTRODUCTION $\ldots \ldots \ldots \ldots \ldots \ldots \ldots \ldots \ldots \ldots \ldots \ldots \ldots \ldots \ldots \ldots, 1$

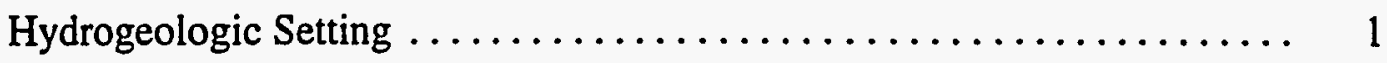

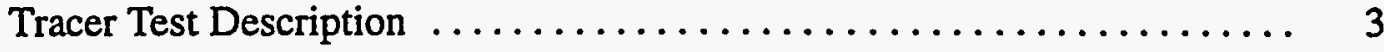

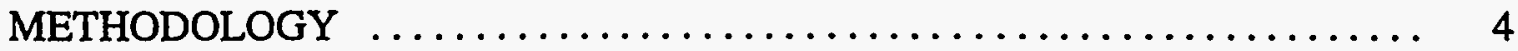

Model Description .............................. 4

Modeling Procedure $\ldots \ldots \ldots \ldots \ldots \ldots \ldots \ldots \ldots \ldots \ldots \ldots \ldots \ldots \ldots \ldots$

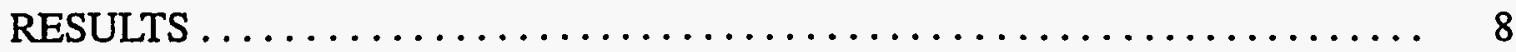

Flow Model Simulation During the Tracer Test $\ldots \ldots \ldots \ldots \ldots \ldots \ldots, 8$

Transport Model During the Tracer Test $\ldots \ldots \ldots \ldots \ldots \ldots \ldots \ldots \ldots, 10$

Long-Term Flow Model Simulation $\ldots \ldots \ldots \ldots \ldots \ldots \ldots \ldots \ldots, 12$

Long-Term Transport Model Simulation ................. 16

CONCLUSIONS AND RECOMMENDATIONS $\ldots \ldots \ldots \ldots \ldots \ldots \ldots \ldots \ldots$

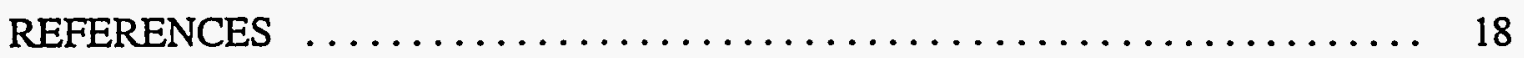




\section{EXECUTIVE SUMMARY}

A recirculated tracer test was performed in the fractured Culebra Dolomite aquifer at the Gnome Site, New Mexico in March 1963. The tritium data collected during the tracer test and from long-term monitoring of the local wells were used in conjunction with a numerical groundwater flow and transport model to further characterize the hydraulic properties of the aquifer and to determine if the injected tritium was the primary source of tritium found in the long-term monitoring.

MODFLOW (McDonald and Harbaugh, 1988) was used to simulate the groundwater flow conditions during the tracer test experiment. The model was calibrated to the observed drawdown $(11 \mathrm{~m})$ in the pumping well. A transmissivity value of $14 \mathrm{~m}^{2}$ day ${ }^{-1}$ was found to effectively simulate the observed flow conditions.

MT3D (Papadopulos and Associates, 1992) was used to simulate the transport of radionuclides during a recirculating tracer test experiment. The observed tritium concentrations were used to calibrate the transport model by adjusting the porosity and longitudinal dispersivity. An excellent agreement between the observed and simulated tritium concentrations was met with a porosity of 0.115 and dispersivity of $24 \mathrm{~m}$. This calibrated model was then used to simulate regional flow conditions following the tracer test experiment. A reasonable agreement was met between the simulated and observed long-term tritium concentrations when a regional gradient of $4.2 \times 10^{-4}$ was used. There is considerable uncertainty in the regional gradient estimate, but the simulated value was within the reported range. Due to the uncertain water level measurements near the Gnome site, it is recommended that the wellheads be surveyed and the current water levels and aquifer gradient be obtained. This additional hydraulic information is critical to the understanding of the groundwater flow and transport in this region. If the true gradient can be approximated by the simulated value of $4.2 \times 10^{-4}$, then the tritium $(18.5 \mathrm{Ci}$ ) injected during the tracer test experiment is most likely the only source that was found during the long-term monitoring.

It should be noted that the assumptions used in this modeling study may not represent the true aquifer conditions. The flow and transport model used "effective" parameters to represent the heterogeneous domain. These "effective" parameters were found by numerical inverse procedures and may not represent the aquifer system with enough certainty to simulate long-term flow and transport. Specifically, the dispersivity parameter was estimated for an induced hydraulic gradient imposed by the pumping and injection wells and may not represent the aquifer under ambient flow conditions used in the long-term simulations. 


\section{FIGURES}

1. Setting of the Gnome site in the northem Delaware Basin........... 2

2. General MODFLOW model conditions near the Gnome site. ........ 5

3. Simulated steady-state hydraulic head distribution in the Culebra Dolomite aquifer for the tracer test simulation. ................ 9

4. The "best-fit" simulation for the relative tritium breakthrough data. ..... 10

5. Sensitivity of the RMSE (observed versus simulated tritium breakthrough) to porosity and dispersivity. $\ldots \ldots \ldots \ldots \ldots \ldots \ldots \ldots \ldots \ldots \ldots \ldots \ldots \ldots \ldots, 11$

6. The "best-fit" simulation for the hand-drawn tritium breakthrough data. ... 12

7. Sensitivity of the RMSE (observed versus simulated tritium breakthrough)

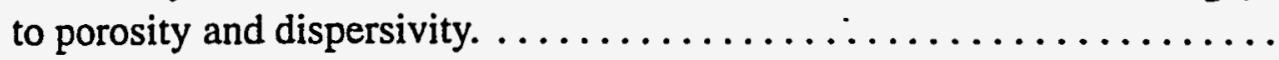

8. Simulated areal distribution of tritium in the Culebra Dolomite aquifer at the termination of the tracer test experiment (day 16). .......... 14

9. Hydraulic head distribution for the long-term flow model. .......... 15

10. Simulated and observed breakthrough curves for tritium at USGS\#4 and USGS\#8 (Gradient $\left.=4.2 \times 10^{-4}\right) \ldots \ldots \ldots \ldots \ldots \ldots \ldots \ldots \ldots \ldots \ldots$

11. Simulated and observed breakthrough curves for tritium at USGS\#4 and USGS\#8 (Gradient $\left.=2.32 \times 10^{-3}\right)$

\section{TABLES}

1. Gnome Groundwater Modeling Sensitivity Analysis for the Tracer Test Simulation. 


\section{INTRODUCTION}

A radionuclide tracer test was conducted in 1963 by the U.S. Geological Survey at the Project Gnome underground nuclear test site, approximately $40 \mathrm{~km}$ southeast of Carlsbad, New Mexico. The tracer study was carried out under the auspices of the U.S. Atomic Energy Commission (AEC) to study the transport behavior of radionuclides in fractured rock aquifers. The Culebra Dolomite was chosen for the test because it was considered to be a reasonable analogue of the fractured carbonate aquifer at the Nevada Test Site (NTS), the principal location of U.S. underground nuclear tests.

Project Gnome was one of a small number of underground nuclear tests conducted by the AEC at sites distant from the NTS. The Gnome device was detonated on December 10, 1961 in an evaporite unit at a depth of $360 \mathrm{~m}$ below ground surface. Recently, the U.S. Department of Energy (DOE) implemented an environmental restoration program to characterize, remediate, and close these offsite nuclear test areas. An early step in this process is performance of a preliminary risk analysis of the hazard posed by each site. The Desert Research Institute has performed preliminary hydrologic risk evaluations for the groundwater transport pathway at Gnome (Earman et al., in press). That evaluation included the radioactive tracer test as a possible source because the test introduced radionuclides directly into the Culebra Dolomite, which is the only aquifer at the site.

This report presents a preliminary evaluation of the radionuclide tracer test as a source for radionuclide migration in the Culebra Dolomite. Movement of the radionuclide tracers during the tracer test is numerically modeled to delineate the approximate distribution of tracers around the test wells. This model is calibrated to the tritium breakthrough data produced during the original tracer test. Radionuclide concentrations in the test wells following the tracer test are then simulated and compared to monitoring data collected from these wells by the U.S. Environmental Protection Agency (EPA). The results of this evaluation will assist in planning site characterization activities and refining estimates of the radionuclide source for comprehensive models of groundwater transport at the Gnome site.

\section{Hydrogeologic Setting}

The geology and hydrogeology of the Project Gnome site are described by Gard (1968), Cooper (1962a), Cooper (1962b), and Cooper and Glanzman (1971). The Gnome site is located in the northern portion of the Delaware Basin (Figure 1), which contains up to $5,550 \mathrm{~m}$ of sedimentary rocks deposited in a Permian-age sea. The tracer test was conducted in the Culebra Dolomite Member of the Rustler Formation.

The Culebra Dolomite lies approximately $156 \mathrm{~m}$ below ground surface and is the only aquifer present at the Gnome site. Most groundwater movement within the Culebra occurs in fractures (Cooper and Glanzman, 1971). The Culebra is approximately $10.4 \mathrm{~m}$ thick at the tracer site and ranges between 9 and $12 \mathrm{~m}$ thick throughout the Delaware Basin (Gard, 1968). The remainder of the Rustler Formation consists primarily of gypsum and anhydrite and generally has very low hydraulic conductivity. 


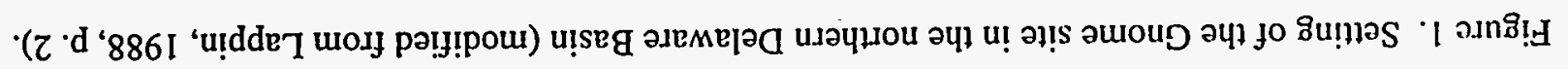

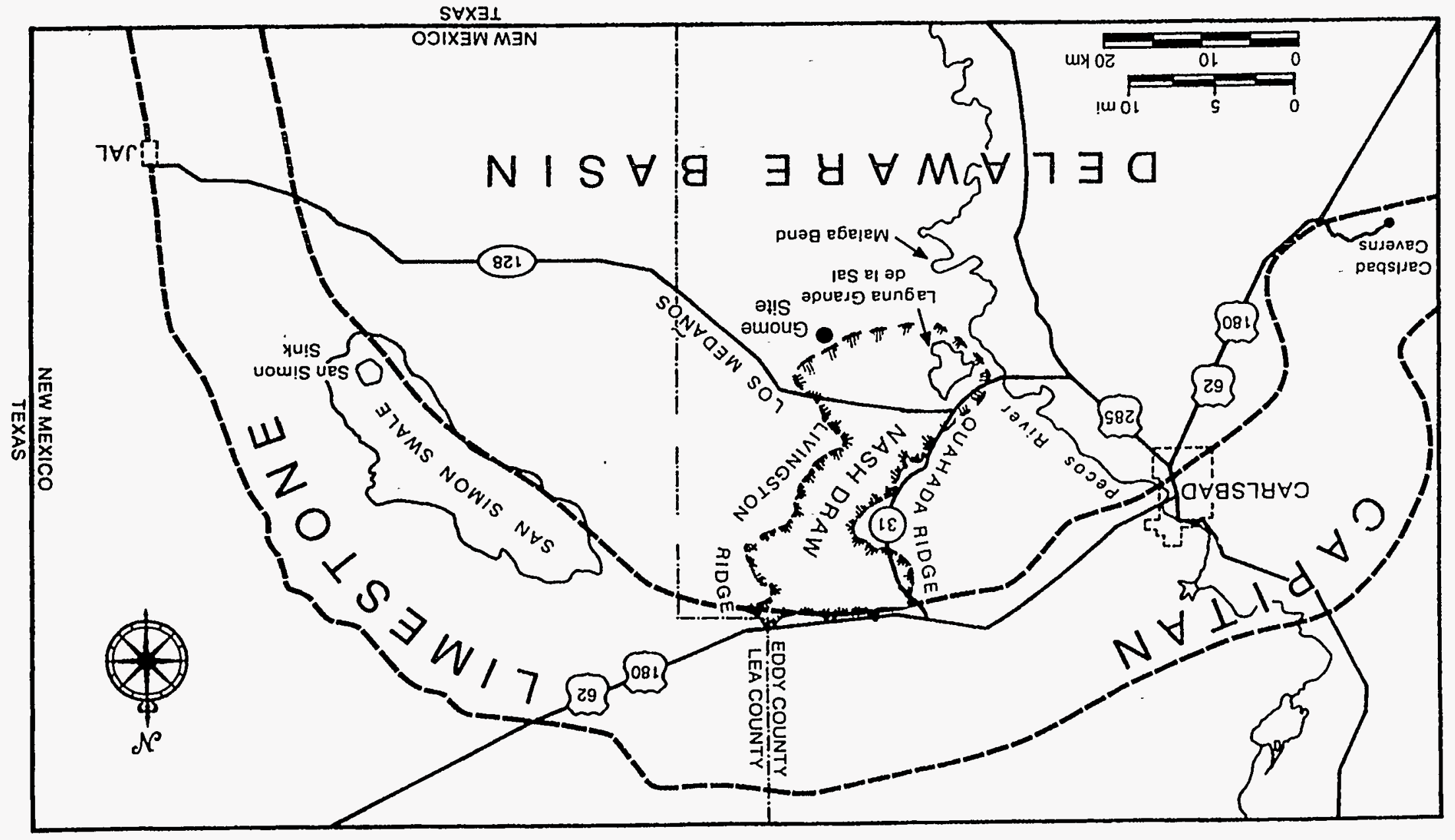


Groundwater in the Culebra flows in a westward or southwestward direction from the site and is thought to be discharged at the Pecos River (Cooper and Glanzman, 1971).

\section{Tracer Test Description}

The tracer test was designed to collect the breakthrough data necessary to estimate values of the dispersion coefficient (dispersivity) and effective porosity of the Culebra Dolomite using a method presented by Grove and Beetem (1971). This information was desirable for improving the understanding and prediction of radionuclide transport in a fractured-rock aquifer similar to carbonate aquifers present at the NTS (Beetem and Angelo, 1964).

Grove and Beetem (1971) provide the theoretical development for the two-well recirculating tracer test. In this test, one well discharges from the aquifer and the second well injects the water pumped from the first at the same rate to create a steady-state flow field between the wells. The authors suggest that injecting a tracer into the steady-state flow field via the injection well, measuring tracer concentrations at the discharge well, and then comparing the measured tracer breakthrough to analytically simulated breakthrough curves can provide estimates of the dispersion coefficient and the effective porosity of the aquifer. It should be noted, however, that this type of tracer test is conducted not under the ambient hydraulic gradient of the aquifer but under the induced hydraulic gradient caused by the pumping and injection wells. Therefore, the parameters estimated from this technique may not represent the aquifer under ambient flow conditions.

The design and operation of the tracer test is described by Beetem and Angelo (1964). Two wells were constructed: injection well USGS\#8 is approximately $915 \mathrm{~m}$ west of Project Gnome ground zero and discharge well USGS\#4 is $38 \mathrm{~m}$ due west of USGS\#8. Deviation from the vertical in USGS\#4 caused the wells to be separated by approximately $55 \mathrm{~m}$ in the Culebra. Both wells are uncased throughout the 10.4-m thickness of the Culebra. A 15.24-cm-diameter steel pipe connecting the two wells provided for recirculation of the groundwater and tracers from the discharge well to injection well. In the first phase of the test (February 9-15, 1963), the discharge well was pumped at $168 \mathrm{~L} / \mathrm{min}$ until the discharge and recharge pressure responses indicated that flow conditions between the wells were approaching steady state. Unknown quantities of the conservative tracers tritium and fluorescein were then added to the injection line to determine their dilution factors, and pumping continued for seven days while samples were collected from the discharge line. The pump was shut off and fluid pressures allowed to recover for two weeks prior to the initiation of the second phase of testing. The pump was started for the second phase on February 21, 1963, and steady-state conditions reestablished, followed by the addition of slugs of $18.5 \mathrm{Ci}$ of ${ }^{3} \mathrm{H}, 10 \mathrm{Ci}$ of ${ }^{137} \mathrm{Cs}, 10 \mathrm{Ci}$ of ${ }^{90} \mathrm{Sr}$, and $4 \mathrm{Ci}$ of ${ }^{131} \mathrm{I}$ to the injection line. Pumping continued for 16 days while samples were collected from the discharge line.

The test was terminated on March 9, 1963, after the breakthrough curves were considered to be sufficiently developed for the analysis. Subsequent to the test, the discharge/injection pipe system was dismantled, the pump in USGS\#4 was pulled, and the surface area cleaned up (Beetem and Angelo, 1964). However, no records are available that describe efforts to remediate the Culebra dolomite and the radioactive tracers therein. This study takes a conservative approach and assumes 
that the tracers were not removed after the test and, therefore, were free to be transported by groundwater.

\section{METHODOLOGY}

\section{Model Description}

Two numerical models were used to simulate the groundwater flow and radionuclide transport within the Culebra Dolomite aquifer at the Gnome Site. The primary objective was to simulate radionuclide transport during and subsequent to the recirculating tracer test experiment that was performed in March 1963. First, MODFLOW (McDonald and Harbaugh, 1988) was used to simulate the hydraulic head distribution and flow velocities given certain aquifer parameters such as transmissivity, regional hydraulic head gradient and pumping rates. Once completed, the output from the flow simulation was used as input in the transport simulation. MT3D (Papadopulos and Associates, 1992) was used to solve the advection and dispersion equation to simulate radionuclide contaminant transport.

Immediately before the tracer test the flow system was assumed to be in steady state with no pumping. The tracer test was simulated by applying the injection from well USGS\#8 $\left(241.9 \mathrm{~m}^{3}\right.$ day $\left.^{-1}\right)$ and the pumping well $\left(241.9 \mathrm{~m}^{3}\right.$ day $\left.^{-1}\right)$ (Grove and Beetem, 1971). Field observations indicated that the aquifer reached equilibrium conditions within minutes of the onset of pumping. As such, two separate steady-state simulations were used to simulate the conditions of the second tracer test (16 days) and the regional flow conditions afterward. MODFLOW was used to simulate steady-state groundwater flow in a confined aquifer, which can be described by the partial-differential equation:

$$
\frac{\partial}{\partial \mathrm{x}_{\mathrm{i}}}\left(\mathrm{K}_{\mathrm{ii}} \frac{\partial \mathrm{h}}{\partial \mathrm{x}_{\mathrm{j}}}\right)-\mathrm{q}_{\mathrm{s}}=0
$$

where $\mathrm{i}$ and $\mathrm{j}$ indicate $\mathrm{x}$ or $\mathrm{y}$ spatial coordinates, $\mathrm{K}_{\mathrm{xx}}$ and $\mathrm{K}_{\mathrm{yy}}\left[\mathrm{m} \mathrm{day}^{-1}\right]$ are the horizontal components of aquifer hydraulic conductivity, $\mathrm{q}_{\mathrm{s}}$ is a volumetric flux per unit volume of aquifer and represents sources and/or sinks of water [day ${ }^{-1}$ ] and $h$ is the hydraulic head [m]. The Culebra Dolomite aquifer was simulated with one layer (i.e., two-dimensional) and was discretized into 40,000 (5 x $5 \mathrm{~m}$ ) finite difference elements. The east and west boundaries were simulated as Type 3 head-dependent (Type 3) boundaries to effectively represent the observed regional head gradient. Groundwater flow across head-dependent (Type 3) flow boundaries is proportional to the difference in hydraulic head at a point exterior to the boundary. The conductance is defined as (McDonald and Harbaugh, 1988):

$$
\mathrm{CB}=\frac{\mathrm{KA}}{\mathrm{L}}
$$

where $\mathrm{CB}$ is the hydraulic conductance across the boundary $\left[\mathrm{m}^{2}\right.$ day $\left.^{-1}\right], \mathrm{K}$ is the horizontal hydraulic conductivity [ $\left.\mathrm{m}_{\text {day }}{ }^{-1}\right], A$ is the area of the face of the section adjacent to the head-dependent flow boundary $\left[\mathrm{m}^{2}\right]$ and $\mathrm{L}$ is the distance from the edge of the model to the location of the head dependent flow boundary $[\mathrm{m}]$. Because the primary regional flow direction is from east to west, the north and south boundaries were assumed to be no-flow boundaries. Figure 2 shows the general model domain 


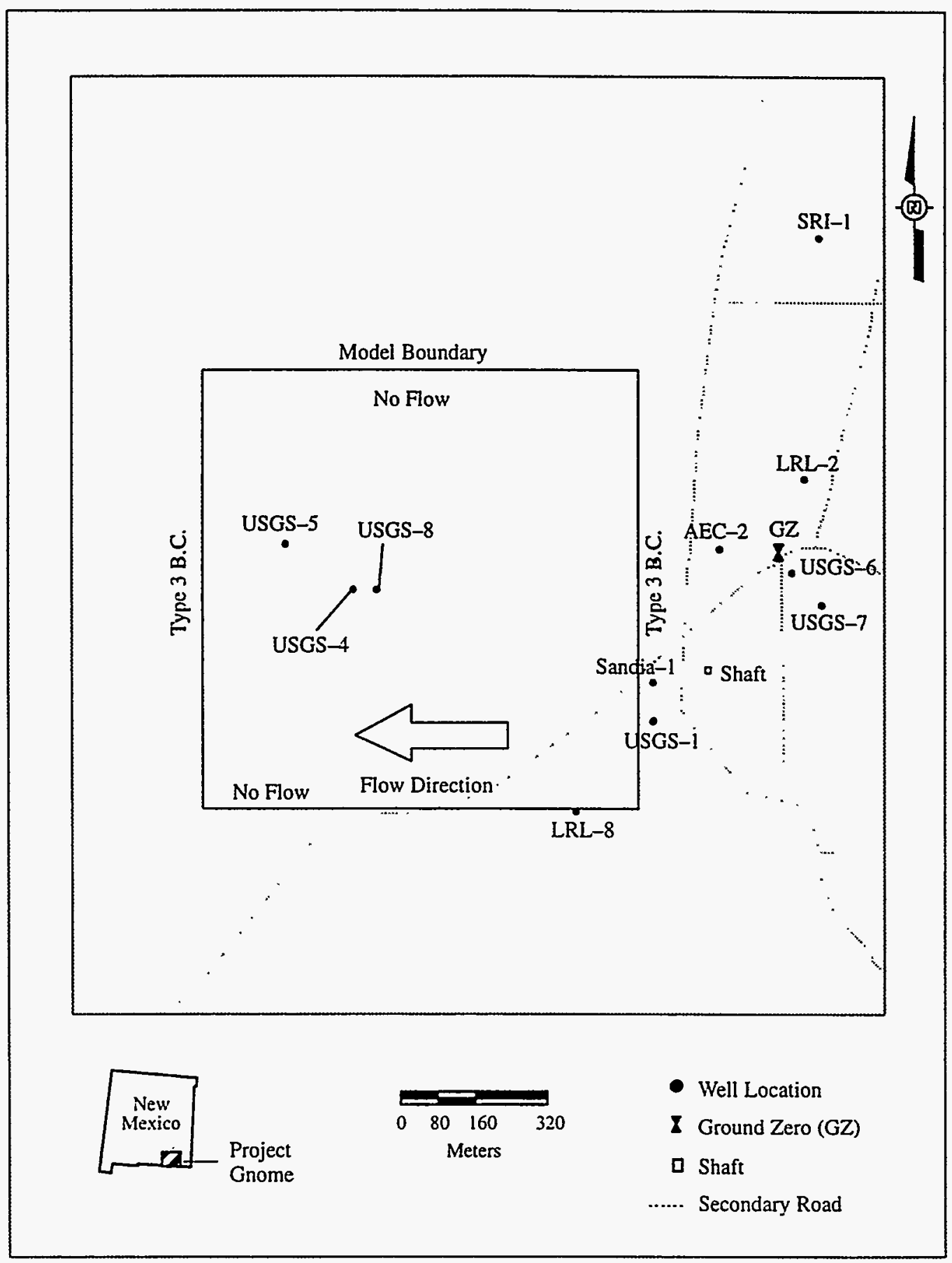

Figure 2. General MODFLOW model conditions near the Gnome site. 
and boundary conditions in relation to the local wells at the Gnome site. The size of the model domain $(1000 \times 1000 \mathrm{~m})$ was set such that boundary effects would not influence the simulated results. The fractured nature of the Culebra aquifer is not a traditional homogenous porous medium, but it was assumed to behave as a homogenous unit at the scale of the simulation. As such, an effective transmissivity was estimated using a "trial and error" calibration. The transmissivity was adjusted until the simulated drawdown was in agreement with the observed drawdown $(11 \mathrm{~m})$ at the pumping well. The sensitivity of the flow simulation to the regional gradient and effective transmissivity was evaluated. The regional flow simulation after the tracer test was constructed with a regional gradient of $4.2 \times 10^{-4}$ and no pumping. There was considerable uncertainty in the regional gradient estimate, so the sensitivity of the transport solution was tested with a range of regional gradients $\left(2.3 \times 10^{-3}-4.2 \times 10^{-4}\right)$.

The radionuclide transport was simulated with MT3D, which can be described by the partial differential equation:

$$
R \frac{\partial C}{\partial t}=\frac{\partial}{\partial x_{i}}\left(D_{i j} \frac{\partial C}{\partial x_{j}}\right)-\frac{\partial}{\partial x_{i}}\left(v_{i} C\right)+\frac{q_{s}}{\theta} C_{s}-\lambda\left(C+\frac{Q_{b}}{\theta} C^{\prime}\right)
$$

where $C$ is the concentration of the radionuclide dissolved in groundwater $\left[\mathrm{pCi} \mathrm{L}^{-1}\right], \mathrm{C}^{\prime}$ is the concentration of the radionuclide sorbed on the porous medium [ $\mathrm{g} \mathrm{g}^{-1}$ ], $t$ is time [days], $\mathrm{x}_{\mathrm{i}}$ is the distance along the respective Cartesian coordinate axis $[\mathrm{m}], \mathrm{v}_{\mathrm{i}}$ is the linear pore water velocity [m day $\left.^{-1}\right], q_{s}$ is the volumetric flux of water per unit volume of aquifer representing sources and/or sinks [day ${ }^{-1}$ ], $\mathrm{C}_{s}$ is the concentration of the sources or sinks [pCi L-1 ], $\theta$ is the porosity of the porous medium [dimensionless], and $D_{i j}$ is the hydrodynamic dispersion coefficient $\left[\mathrm{m}^{2}\right.$ day $\left.{ }^{-1}\right]$ defined as:

$$
\begin{aligned}
& D_{x x}=\alpha_{L} \frac{v_{x}^{2}}{|v|}+\alpha_{T H} \frac{v_{y}^{2}}{|v|}+D^{*} \\
& D_{y y}=\alpha_{L} \frac{v_{y}^{2}}{|v|}+\alpha_{T H} \frac{v_{x}^{2}}{|v|}+D^{*} \\
& D_{x y}=D_{y x}=\left(\alpha_{L}-\alpha_{T H}\right) \frac{v_{x} v_{y}}{|v|}
\end{aligned}
$$

where $\alpha_{L}$ is the longitudinal dispersivity [m] and $\alpha_{T H}$ is the transverse dispersivity (m), $D^{*}$ is the molecular diffusion coefficient $\left[\mathrm{m}^{2}\right.$ day $\left.{ }^{-1}\right]$. The molecular diffusion is inconsequential at the velocities simulated and as such was assumed to be zero for all simulations. The term Ivl is defined as:

$$
|v|=\left(v_{x}^{2}+v_{y}^{2}\right)^{0.5}
$$

The chemical reaction terms in Equation (3) are defined as: $\lambda$ is the first-order rate constant used to simulate radioactive decay. The rate constant is usually given in terms of the half-life:

$$
\lambda=\frac{\ln 2}{t_{1 / 2}}
$$

where $t_{1 / 2}$ is the half-life of the radionuclide. 
The retardation factor $(R)$ [dimensionless] in Equation (3) for a linear isotherm is:

$$
\mathrm{R}=1+\frac{\mathrm{Q}_{\mathrm{b}}}{\theta} \mathrm{K}_{\mathrm{d}}
$$

where $\mathrm{Q}_{b}$ is the bulk density of the aquifer material $\left[\mathrm{g} \mathrm{m}^{-3}\right]$ and $\mathrm{K}_{\mathrm{d}}$ is the distribution coefficient $\left[\mathrm{m}^{3} \mathrm{~g}^{-1}\right]$. Due to the radionuclides being simulated in activity concentrations $\left[\mathrm{pCi} \mathrm{L}^{-1}\right]$, the dimensionless retardation factor was input directly. Previous laboratory experiments have shown that ${ }^{3} \mathrm{H}$ does not sorb onto the Culebra Dolomite (Janzer et al., 1962; Lynch and Dosch, 1980: Pearson et al., 1987).

MT3D was used to simulate the recirculation of radionuclides from the pumping well into the injection well. A mass-balance algorithm was included as:

$$
C_{\text {inj }}=\left(\frac{Q_{\text {inj }} C_{\text {pump }}+Q_{\text {tr }} C_{t r}}{Q_{\text {tot }}}\right)
$$

where $\mathrm{C}_{\mathrm{inj}}$ is the concentration of the injection tracer well [pCi L-1 $], \mathrm{C}_{\mathrm{pump}}$ is the concentration at the pumping well [pCi $\left.{ }^{-1}\right], C_{t r}$ is the concentration of the tracer injection fluid $\left[\mathrm{pCi} \mathrm{L}^{-1}\right]$, $\mathrm{Q}_{\mathrm{inj}}$ is the volumetric injection rate at the injection well $\left[\mathrm{m}^{3}\right.$ day $\left.^{-1}\right], \mathrm{Q}_{\mathrm{tr}}$ is the volumetric flow rate of the tracer flow line $\left[\mathrm{m}^{3}\right.$ day $\left.^{-1}\right]$ and $\mathrm{Q}_{\mathrm{tot}}=\mathrm{Q}_{\mathrm{tr}}+\mathrm{Q}_{\mathrm{inj}}$. The pumping lasted at total of 16 days, while the tracer was injected for only 7.76 days (Grove and Beetem, 1971).

\section{Modeling Procedure}

The following lists the modeling procedure during and subsequent to the tracer test experiment:

1. Calibrate MODFLOW simulation during tracer test using one homogeneous transmissivity value (transmissivity $=$ [hydraulic conductivity] [aquifer thickness] [=] $\mathrm{m}^{2}$ day $\left.^{-1}\right)$.

2. Use the output (hydraulic heads and flow velocities) from the calibrated MODFLOW model as input to the MT3D transport simulator to calculate tritium transport during tracer test. Next, a global parameter search was used to estimate the porosity and longitudinal dispersivity such that a reasonable agreement between the observed and simulated tritium breakthrough curves at USGS\#4 was achieved.

3. Verify the calibrated transport simulation by simulating regional flow conditions following the tracer test. Verification was achieved by comparing the long-term transport simulation with observed tritium concentrations at the USGS\#4 and USGS\#8 wells.

4. Perform sensitivity analysis of the long-term tritium transport simulation with regional gradient.

The calibration of the hydraulic system near the Gnome site during the tracer test was performed by adjusting the aquifer transmissivity until the simulated drawdown at USGS\#4 (pumping well) was within $1 \%$ of the observed value of $11 \mathrm{~m}$. This "calibrated" flow simulation was used as input to the transport model. 
The transport model (MT3D) required additional parameters with the effective porosity and dispersivity typically being the most important in terms of simulated concentrations. These parameters were not known; therefore, both parameters were adjusted in regular increments and for each combination of values the simulated breakthrough curve at USGS\#4 was compared with the observed values. To quantify the error between measured and observed breakthroughs a root mean squared error was used as:

$$
\text { RMSE }=\left[\frac{1}{n} \sum_{i=1}^{n}\left(C_{m}-C_{s}\right)_{i}^{2}\right]^{0.5}
$$

where $\mathrm{C}_{\mathrm{s}}$ and $\mathrm{C}_{\mathrm{m}}$ are the simulated and measured relative tritium concentrations at time $i$, respectively, and $\mathrm{n}$ is the number of measured concentrations. The combination of porosity and dispersivity values that yield the minimum RMSE are assumed to be the "best-fit" parameter values. These "best-fit" values were used in the long-term simulation to predict the migration of the tritium downgradient.

The verification simulation was performed to ascertain the validity of the calibrated flow and transport models and to determine if the tracer test was in fact the sole source of tritium that was observed in USGS\#8 and USGS\#4 during the period of 1971 to 1992. MODFLOW was used to simulate the regional flow conditions following the tracer test with no pumping. All calibrated values from the tracer test simulation were used for this simulation. MT3D was used with the initial conditions supplied from tracer test simulation. The regional head-gradient was not known, so a range of gradients $\left(2.3 \times 10^{-3}\right.$ to $\left.4.2 \times 10^{-4}\right)$ was used (Cooper and Glanzman, 1971).

\section{RESULTS}

\section{Flow Model Simulation During the Tracer Test}

The hydraulic head distribution for the Culebra Dolomite aquifer during the tracer test is shown in Figure 3. The "best-fit" transmissivity value was $14.0 \mathrm{~m}^{2}$ day-1. Table 2 shows the sensitivity of the head drawdown to aquifer transmissivity and regional gradient. The simulated drawdown is highly sensitive to transmissivity but much less so to the regional gradient.

\section{TABLE 2. GNOME GROUNDWATER MODELING SENSITIVITY ANALYSIS FOR THE TRACER} TEST SIMULATION.

\begin{tabular}{ccc}
\hline $\begin{array}{c}\text { Transmissivity } \\
\left(\mathrm{m}^{2} / \text { day }\right)\end{array}$ & $\begin{array}{c}\text { Injection Mound } \\
(\mathrm{m})\end{array}$ & $\begin{array}{c}\text { Drawdown } \\
(\mathrm{m})\end{array}$ \\
\hline Gradient $=2.3 \times 10^{-3}$ & & \\
7.0 & 22.25 & 21.90 \\
14.0 & 11.13 & 10.95 \\
28.0 & 5.57 & 5.48 \\
43.6 & 3.58 & 3.52 \\
Gradient $=5.0 \times 10^{-4}$ & & \\
7.0 & 22.24 & 21.90 \\
14.0 & 11.12 & 10.94 \\
28.0 & 5.56 & 5.48 \\
43.6 & 3.57 & 3.51 \\
\hline
\end{tabular}




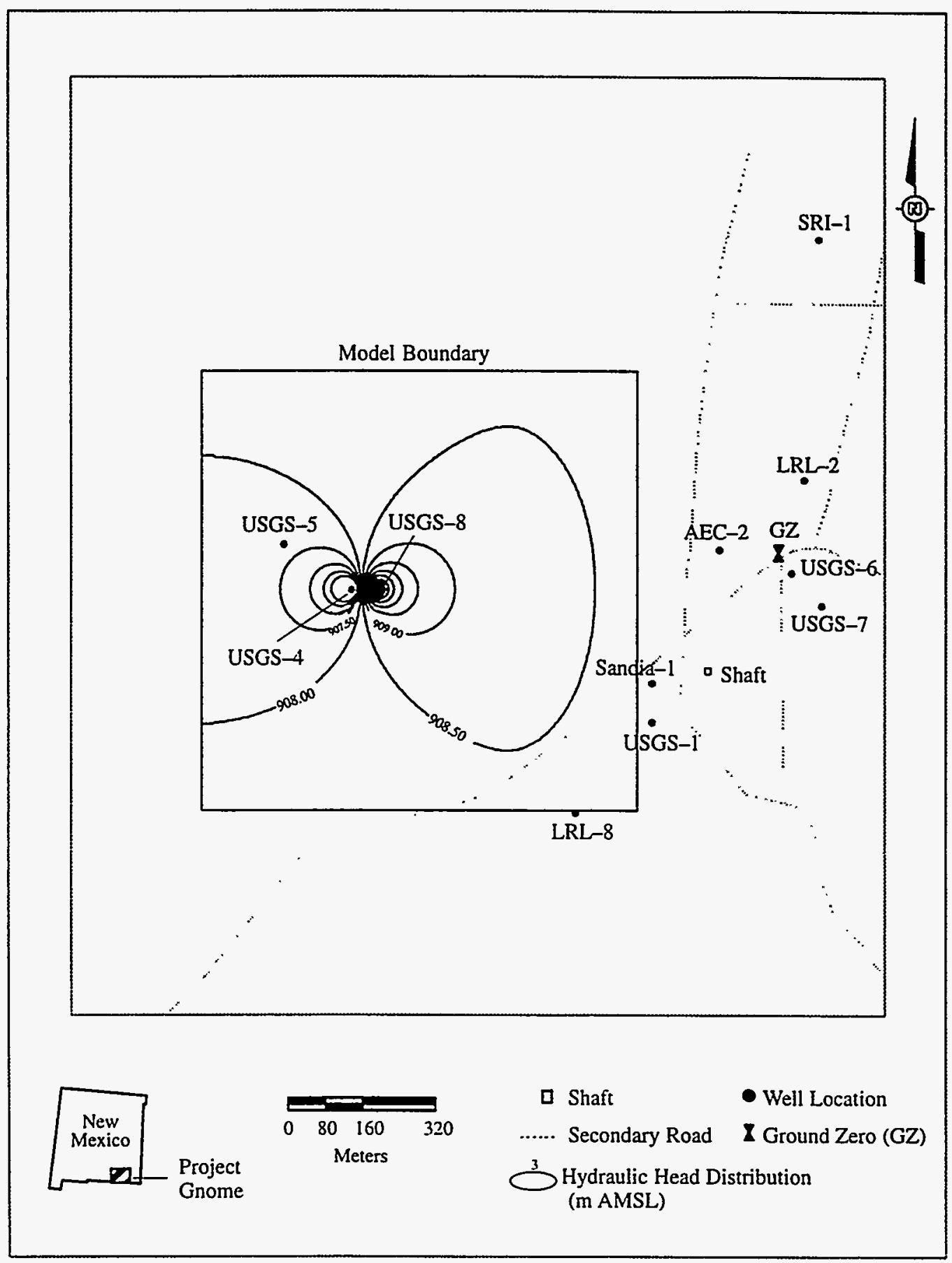

Figure 3. Simulated steady-state hydraulic head distribution in the Culebra Dolomite aquifer for the tracer test simulation. 


\section{Transport Model During the Tracer Test}

There is considerable uncertainty in the available tritium breakthrough data. Two breakthrough curves were found for the tracer test experiment. One is available from Grove and Beetem (1971) with tritium concentration in relative units. An assumption had to be made on what concentration $\left(\mathrm{C}_{0}\right)$ these data were relative to. Typically, the relative concentration is the maximum concentration of the injection well. Assuming $18.5 \mathrm{Ci}$ of injected tritium and 7.76 days of injection at a rate of 241.9 $\mathrm{m}^{3}$ day $^{-1}$, the assumed maximum concentration is $9.85 \times 10^{6} \mathrm{pCi} \mathrm{L}^{-1}$. The second available breakthrough curve was a hand-drawn breakthrough curve from the records obtained from the USGS (D. Wood, personal communication, 1996). These data were presented in radioactive counts $\mathrm{min}^{-1}$ which were then converted to actual tritium concentrations $\left[\mathrm{pCi} \mathrm{L}^{-1}\right]$. The curves are slightly different in terms of timing and magnitude, so two model calibrations were performed. The "best-fit" simulation for the relative tritium breakthrough data reported by Grove and Beetem (1971) is shown in Figure 4. The "best-fit" parameters are $\theta=0.115$ and $\alpha_{L}=24.0 \mathrm{~m}$. The sensitivity of the solution (RMSE of observed versus simulated tritium breakthrough) is shown for porosity and dispersivity in Figure 5 . The plot of RMSE versus porosity and dispersivity suggests a rather unique fit which adds confidence in this model for use as a predictive tool at the scale of the test.

The "best-fit" simulation for the hand-drawn tritium breakthrough data is shown in Figure 6. The parameters which provided the "best-fit" are: $\theta=0.110$ and $\alpha_{L}=26.0 \mathrm{~m}$. The sensitivity of the solution (RMSE of observed versus simulated tritium breakthrough) is shown for porosity and dispersivity in Figure 7. The plot of RMSE versus porosity and dispersivity shows a less unique fit

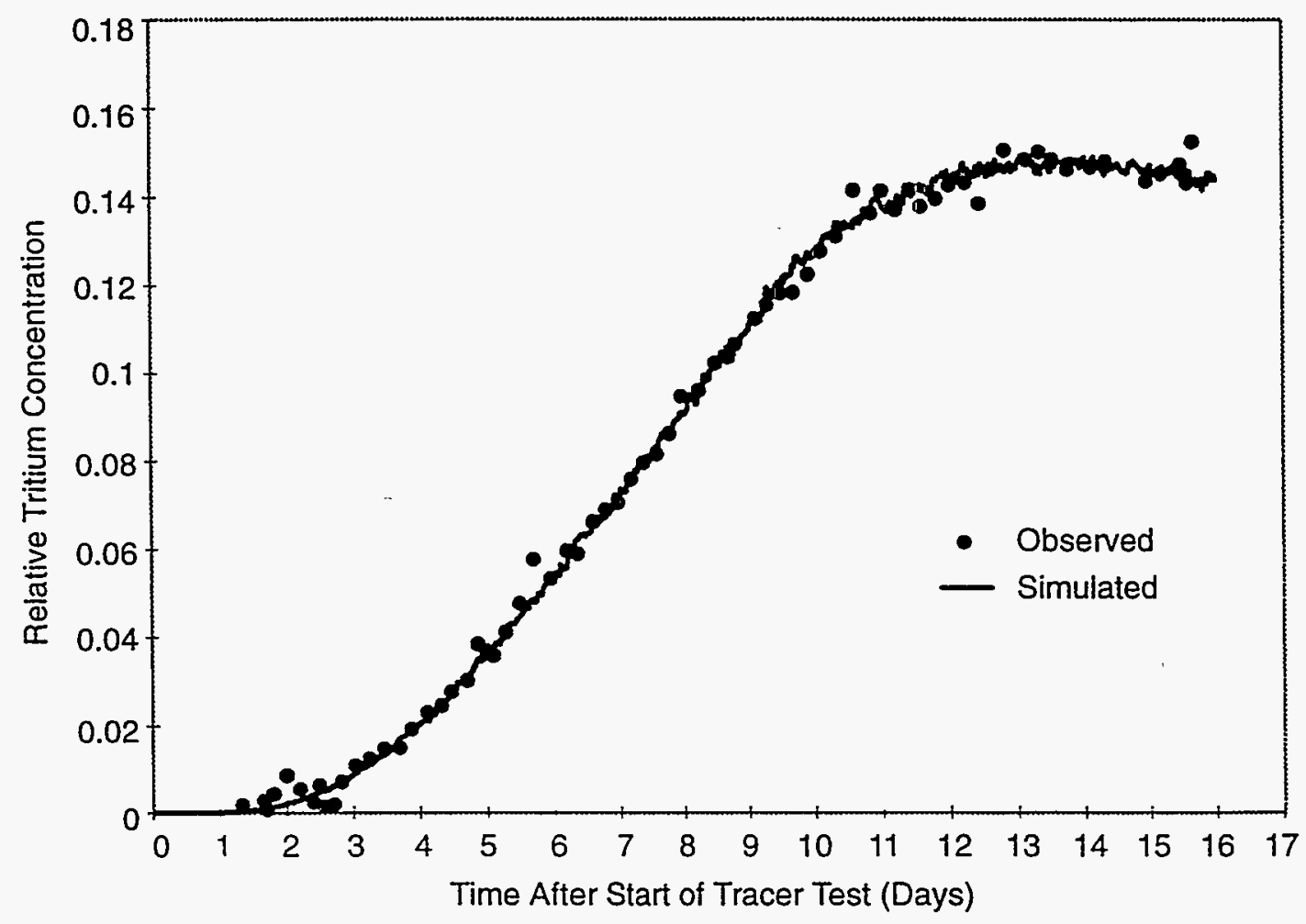

Figure 4. The "best-fit" simulation for the relative tritium breakthrough data (Grove and Beetem, 1971). 


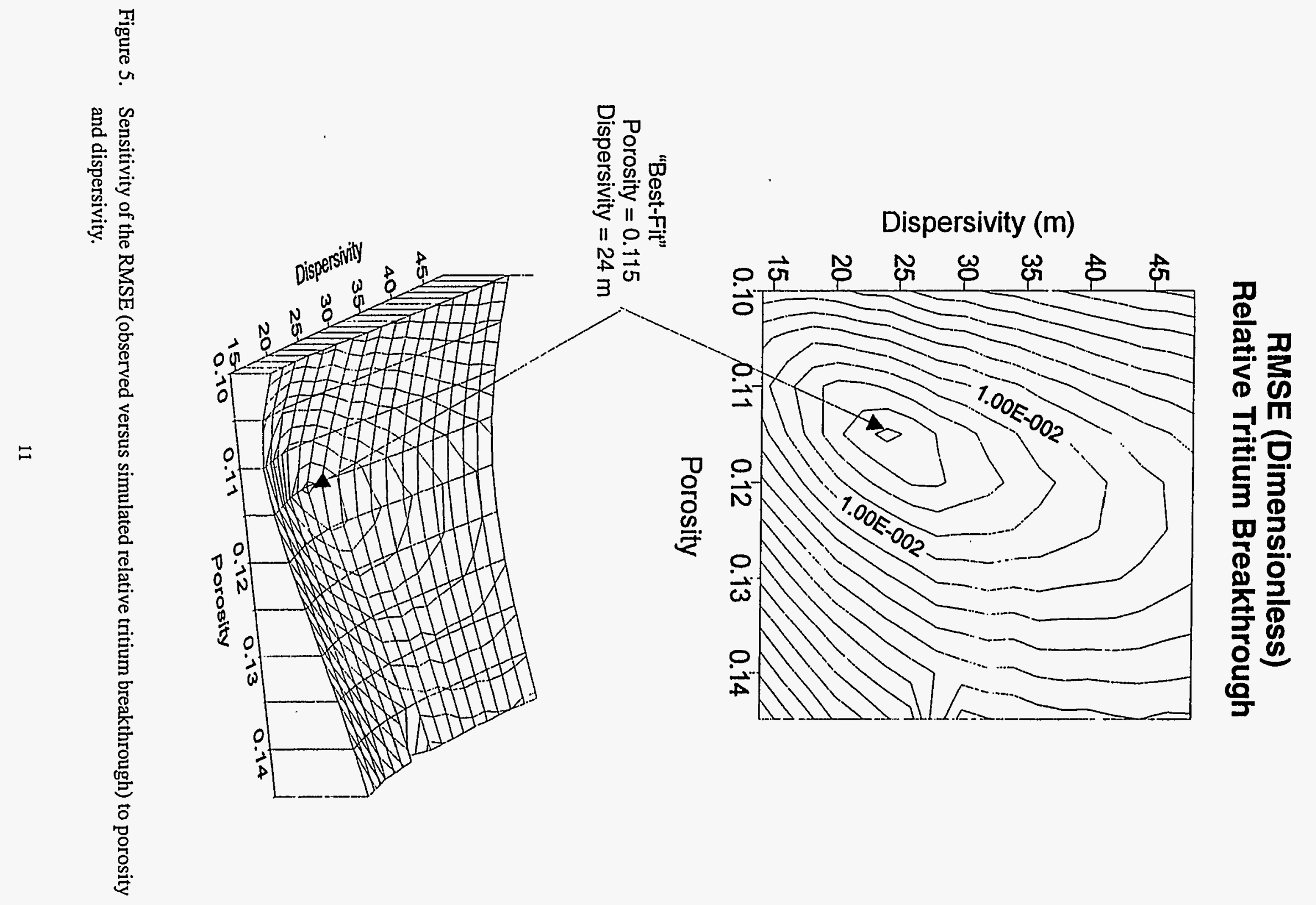




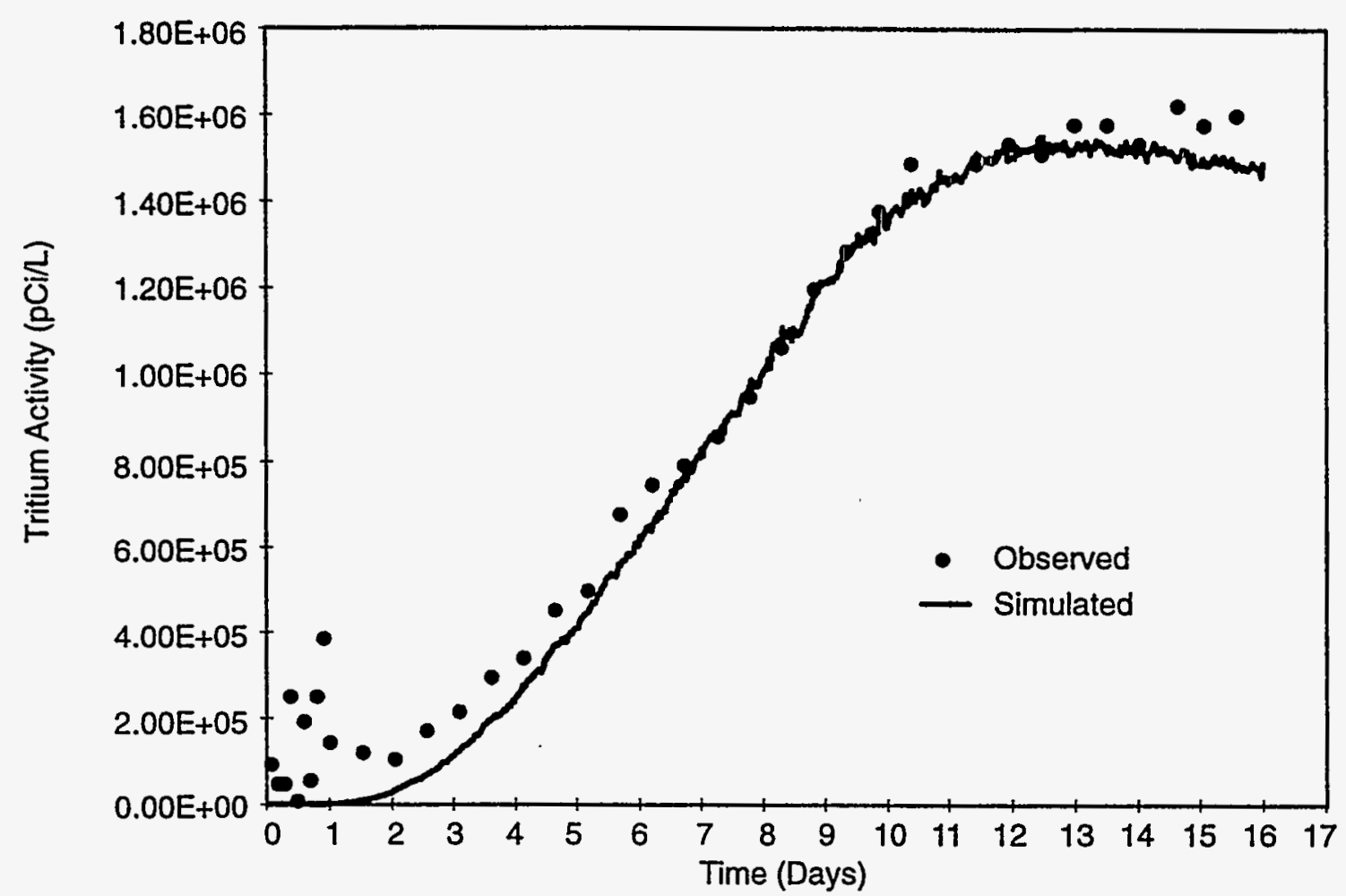

Figure 6. The "best-fit" simulation for the hand-drawn tritium breakthrough data (D. Wood, personal communication, 1996).

than the calibrated simulation using the relative concentration data and the visual fit is clearly not as good. This simulation shows significantly earlier breakthrough than the relative data. Due to the relative concentration data being obtained from a peer-reviewed journal and that the hand-drawn data could not be verified by the original researchers, the "best-fit" parameters from the relative concentration simulation $\left(\theta=0.115\right.$ and $\left.\alpha_{\mathrm{L}}=24.0 \mathrm{~m}\right)$ were used for the long-term simulations.

Figure 8 shows the areal distribution of tritium in the Culebra Dolomite aquifer after the 16-day tracer test (March, 1963) for the $4.2 \times 10^{-4}$ gradient solution. All of the tritium mass is injected during the first 7.76 days of the tracer test with recirculation beginning as soon as the tritium is captured by the pumping well (USGS\#4). The tritium transport during the tracer test is dominated by radial flow away from the injection well with some of the plume being drawn into the pumping well. The pumping well extends the nearly symmetric plume toward the west. After termination of the tracer test, the aquifer is assumed to return to the regional flow condition as shown in Figure 9. The maximum tritium concentration at day 16 of the tracer test is $2.45 \times 10^{6} \mathrm{pCi} \mathrm{L}^{-1}$ and by 1993 it was $2.40 \times 10^{6} \mathrm{pCi} \mathrm{L-1}$.

\section{Long-Term Flow Model Simulation}

The flow and transport parameters for the long-term flow simulation were the same as the tracer test, but pumping was not included. The aquifer was assumed to reach steady-state conditions immediately after pumping ceased. The hydraulic head distribution for the long-term flow 


\section{RMSE (pCi/L) Actual Concentration Tritium Breakthrough}

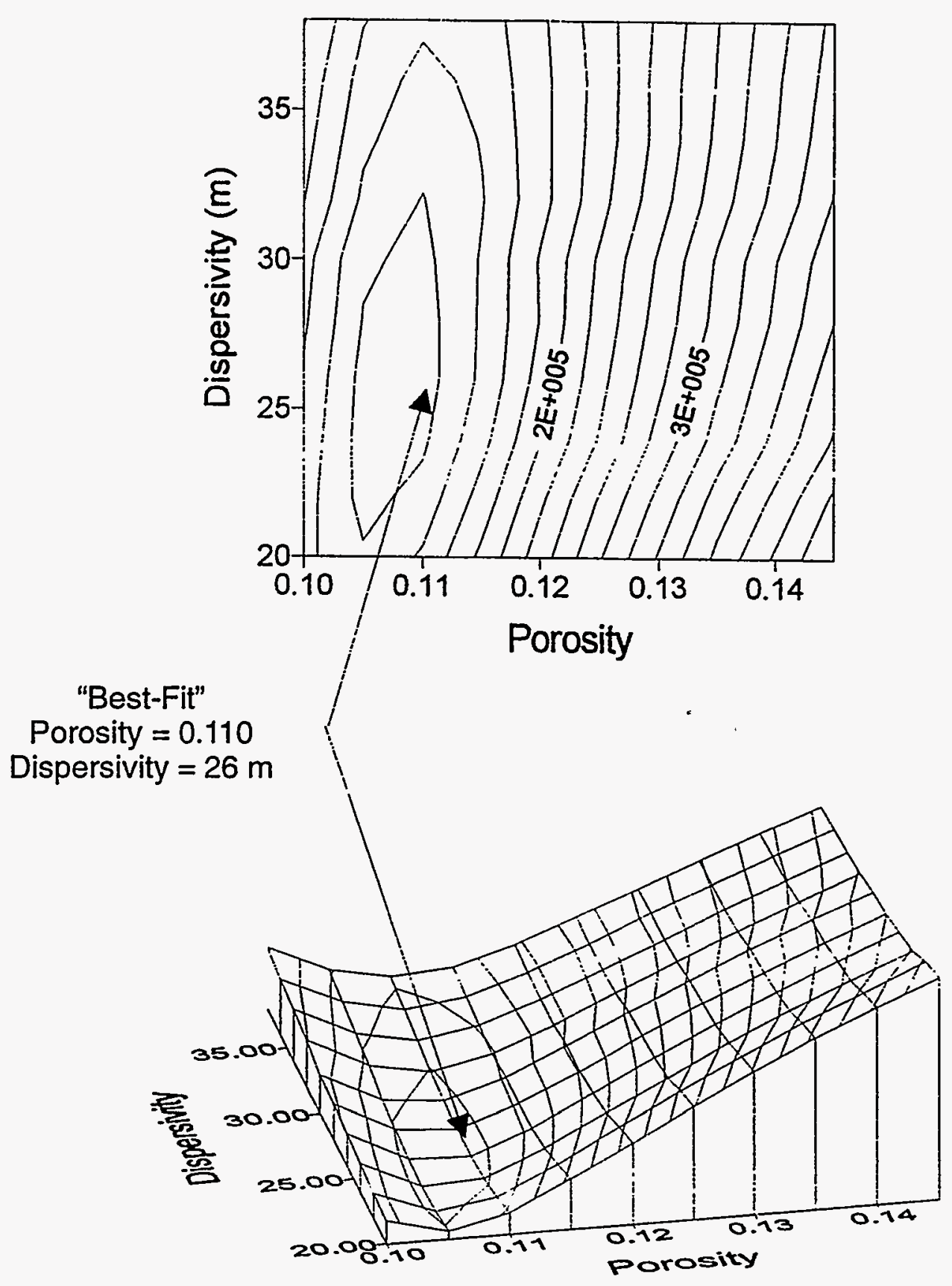

Figure 7. Sensitivity of the RMSE (observed versus simulated actual tritium breakthrough) to porosity and dispersivity. 


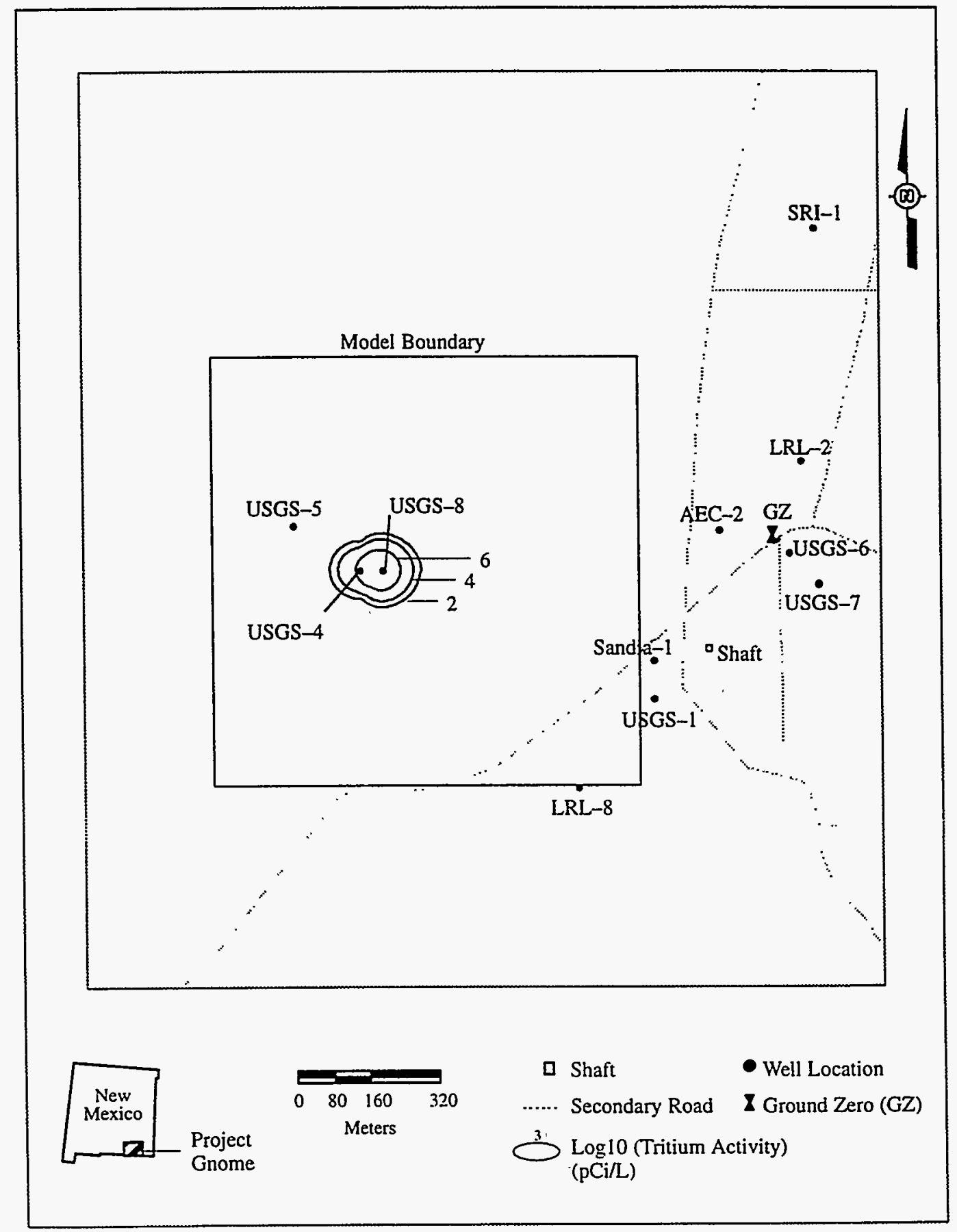

Figure 8. Simulated areal distribution of tritium in the Culebra Dolomite aquifer at the termination of the tracer test experiment (day 16, March, 1963). 


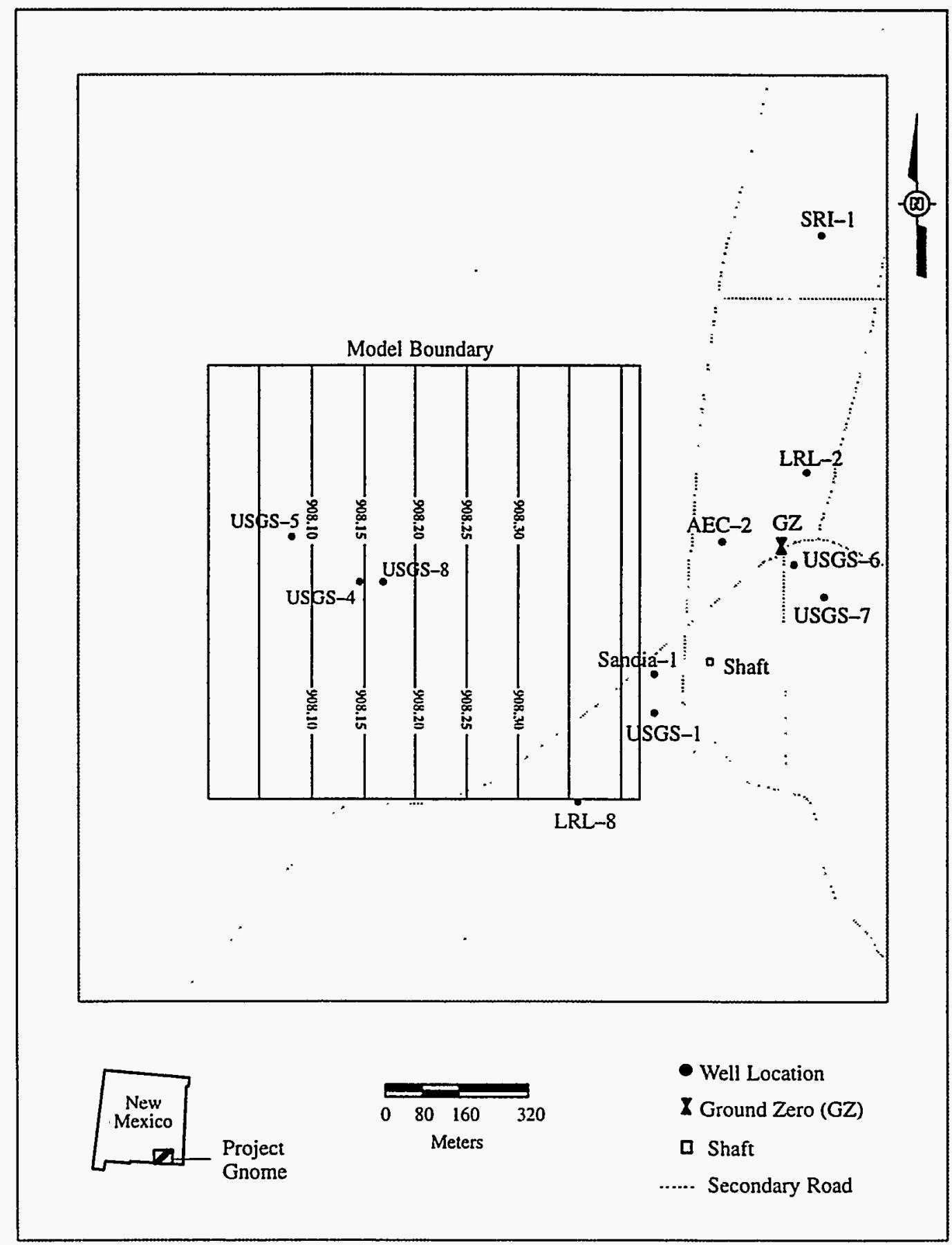

Figure 9. Hydraulic head distribution for the long-term flow model. 
simulation with a regional gradient of $4.2 \times 10^{-4}$ is shown in Figure 9. The regional flow gradient was assumed to be due west. The assumption of a constant hydraulic conductivity field yields a constant gradient.

\section{Long-Term Transport Model Simulation}

The parameters from the calibrated (relative concentration) simulation were used to simulate the tritium transport 30 years (1963 - 1993) beyond the tracer test experiment assuming no pumping and a constant regional gradient. Observation data were available in the USGS\#4 and USGS \#8 wells. The observation data were used to assess the simulation results and to ascertain the possibility of another tritium source, possibly from the Gnome underground nuclear test.

The tritium breakthrough curves for the observed and simulated tritium concentration (Gradient $=4.2 \times 10^{-4}$ ) for USGS\#4 and USGS\#8 are shown in Figure 10. Figure 11 shows the observed and simulated tritium activities for a simulated regional gradient of $2.3 \times 10^{-3}$. Neither simulation is in excellent agreement with the observed values, but the lower gradient $\left(4.2 \times 10^{-4}\right)$ solution is much closer to the observed values, especially at late times. The larger gradient simulation has a much smaller tritium concentration magnitude for the entire simulation. These two simulations show a strong dependence of tritium transport on the regional gradient. It is important to note that this is a verification simulation. The calibration values from the tracer test simulation were used for this long-term simulation. The model parameters could have been adjusted to "fit" the long-term observations, but then the predictive capability of the model would not have been tested. Considering the simplifying assumptions of a homogeneous aquifer, the agreement between the small gradient solution and observed tritium values is quite good.

If the small gradient solution is accepted as a good representation of reality, then the tracer test can be considered the only source of tritium in the USGS\#4 and USGS\#8 wells. There is some uncertainty with the model, therefore, there is some uncertainty in this conclusion.

\section{CONCLUSIONS AND RECOMMENDATIONS}

Radionuclide transport during and subsequent to a 16-day recirculating tracer test was simulated. The flow simulation was calibrated to the observed drawdown of $11 \mathrm{~m}$. The transport simulation was calibrated to the observed tritium breakthrough in the USGS\#4 well. An excellent agreement (RMSE $=6 \times 10^{-3}$ in relative concentration units) was met between the observed and simulated tritium breakthrough curve. A second simulation was performed on another less-certain breakthrough curve that was made available by the USGS (Wood, personal communication, 1996). The simulated breakthrough curve did not perform as well for this secondary data set, but the calibrated values were similar to the original calibration simulation. Due to the uncertainty in the second breakthrough data set, the "best-fit" parameters $\left(\theta=0.115\right.$ and $\left.\alpha_{\mathrm{L}}=24.0\right)$ from the first calibration simulation were used in the long-term simulations.

A long-term simulation was performed to calculate the tritium migration 30 years after the tracer test. The simulated tritium breakthrough curves at the USGS\#4 and USGS\#8 wells were 


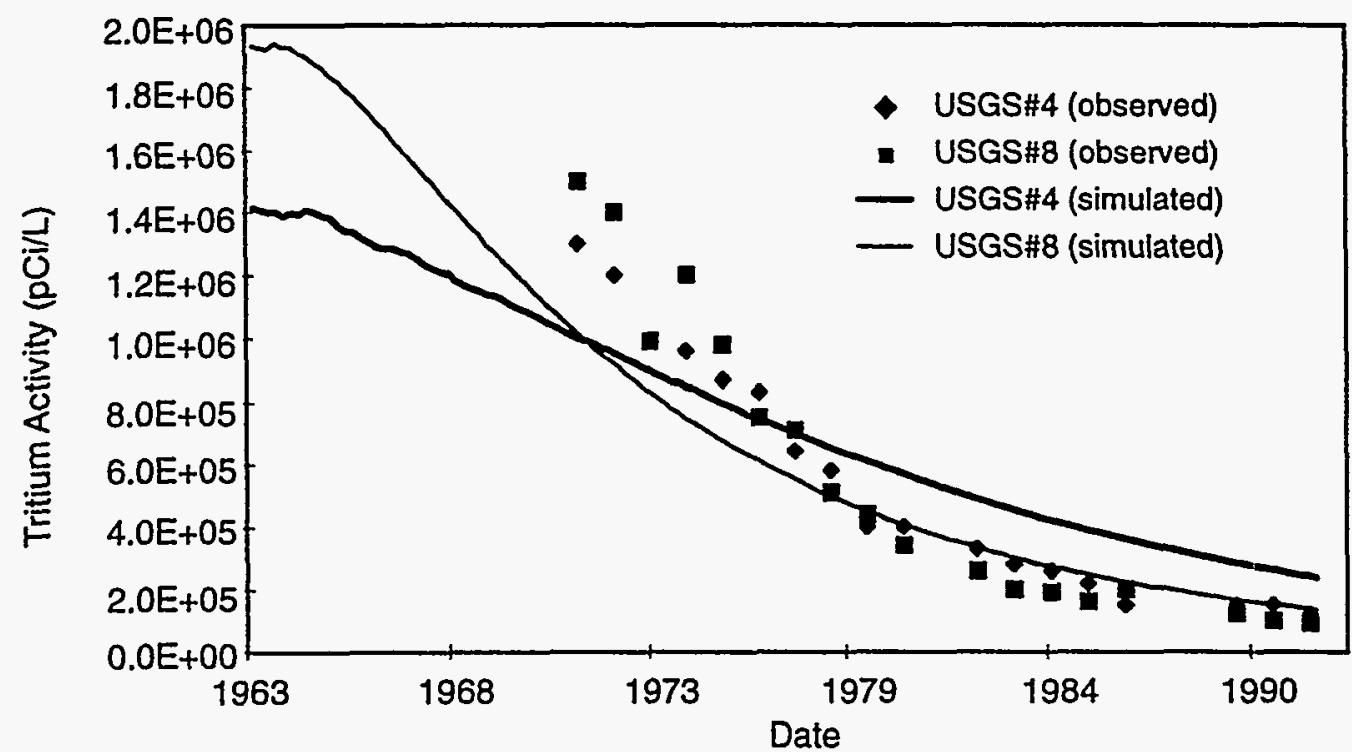

Figure 10. Simulated and observed breakthrough curves for tritium at USGS\#4 and USGS\#8 $\left(\right.$ Gradient $\left.=4.2 \times 10^{-4}\right)$

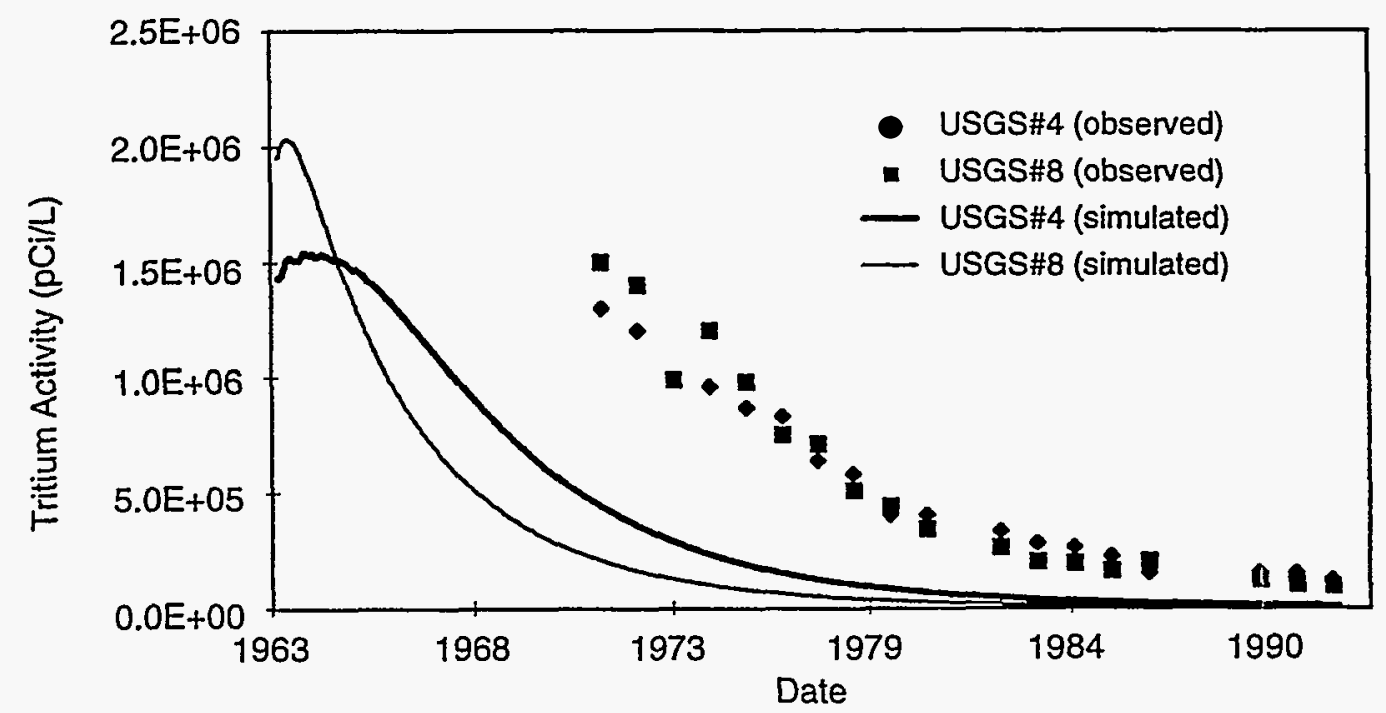

Figure 11. Simulated and observed breakthrough curves for tritium at USGS\#4 and USGS\#8 $\left(\right.$ Gradient $\left.=2.32 \times 10^{-3}\right)$ 
compared against observed values. A range of values was used for this long-term simulation because there was considerable uncertainty in the regional gradient. The simulated tritium breakthrough curve for the large gradient $\left(2.3 \times 10^{-3}\right)$ simulation underestimated the tritium concentration at all times. Using the lower range of the regional gradient $\left(4.2 \times 10^{-4}\right)$, the simulated breakthrough curves were in general agreement with the observed values. The lower regional gradient is within the range published by Cooper and Glanzman (1971) near the tracer test. The lack of accurate water level measurements causes considerable uncertainty in these long-term simulation results.

Assuming that the lower gradient solution is correct, the tracer test is most likely the sole source of tritium found in the monitoring wells. If the larger gradient is closer to reality, then there is a possibility that the source term is larger than assumed. A survey of the wellhead elevations, water levels and regional gradients is necessary to support these conclusions.

Another factor which influences radionuclide transport is aquifer heterogeneity. Heterogeneity was not accounted for in any of the flow or transport simulations. In reality, the Culebra Dolomite aquifer is fractured, which causes significant spatial variability. This is accounted for by the large dispersivity $(24 \mathrm{~m})$. It should be noted that the uniform values used herein are merely "effective" parameters and that the introduction of spatial variability can influence the transport behavior.

\section{REFERENCES}

Beetem, W.A. and C.G. Angelo, 1964. Tracer study at Project Gnome Site, Near Carlsbad, New Mexico - Background information, U.S. Geological Survey Technical Letter: Carlsbad Hydrology-2, Denver, CO.

Cooper, J.B., 1962a. Ground-water investigations of the Project Gnome area, Eddy and Lea counties, New Mexico, Washington, D.C., U.S. Geological Survey, TEI-802.

Cooper, J.B., 1962b. Ground Water, in Atomic Energy Commission, 1962, Final Report, Hydrologic and Geologic Studies (PNE-130F), pp. 112-136.

Cooper, J.B. and V.M. Glanzman, 1971. Geohydrology of Project Gnome Site, Eddy County, New Mexico, Geological Survey Professional Paper 712-A, Washington, D.C.

Earman, S., J. Chapman, K. Pohlmann and R. Andricevic, in press. Assessment of hydrologic transport of radionuclides from the Gnome underground nuclear test site, New Mexico. Desert Research Institute, Water Resources Center Publication No. 45143 (DOE/NV/11508-10).

Gard, L.M., Jr., 1968. Geologic studies, Project Gnome, Eddy County, New Mexico, U.S. Geological Survey Professional Paper 589, United States Government Printing Office, Washington, D.C.

Grove, D.B. and W.A. Beetem, 1971. Porosity and dispersion constant calculations for a fractured carbonate aquifer using the two well tracer method, Water Resources Research, 7(1): 128-134. 
Janzer, V.J., M.C. Goldberg, C.G. Angelo and W.A. Beetem, 1962. Summary of distribution coefficient data for fission products between ground water and rocks from Project Gnome, in U.S. Geological Survey, Hydrologic and geologic studies for Project Gnome - Final Report, PNE-130F.

Lynch, A.W. and R.G. Dosch, 1980. Sorption coefficients for radionuclide on samples from the water-bearing Magenta and Culebra members of the Rustler Formation. Sandia National Laboratories, SAND80-1064.

McDonald, M.G. and A.W. Harbaugh, 1988. A modular three-dimensional finite difference ground-water flow model, Techniques of water-resources investigations of the U.S. Geological Survey, Book 6, Modeling Techniques, Chapter A1.

Papadopulos and Associates, 1992. MT3D - a modular three-dimensional transport model Documentation and user's guide.

Pearson, Jr., F.J., V.A. Kelley and J.F. Pickens, 1987. Preliminary design for a sorbing tracer test in the Culebra Dolomite at the H-3 Hydropad at the Waste Isolation Pilot Plant (WIPP) Site. Sandia National Laboratories Contractor Report SAND86-7177. 


\section{DISTRIBUTION}

Janet Appenzeller-Wing

Environmental Restoration Division Nevada Operations Office

U.S. Department of Energy

P.O. Box 98518

Las Vegas, NV 89193-8518

Bob Bangerter

Environmental Restoration Division

Nevada Operations Office

U.S. Department of Energy

P.O. Box 98518

Las Vegas, NV 89193-8518

Joanne M. Bradbery, Director

Contract Management Division

Nevada Operations Office

U.S. Department of Energy

P.O. Box 98518

Las Vegas, NV 89193-8518

Frank Di Sanza, Director

Energy Technologies Division

Nevada Operations Office

U.S. Department of Energy

P.O. Box 98518

Las Vegas, NV 89193-8518

Doug Duncan

Hydrology Program Manager

Environmental Protection Division

Nevada Operations Office

U.S. Department of Energy

P.O. Box 98518

Las Vegas, NV 89193-8518

Virginia Glanzman

U.S. Geological Survey

Box 2506, MS 913

Denver Federal Center

Denver, CO 80225
Paul Gretsky

International Technology Corporation 4330 S. Valley View

Suite 114

Las Vegas, NV 89103

Kenneth Hoar, Director

Environmental Protection Division

Nevada Operations Office

U.S. Department of Energy

P.O. Box 98518

Las Vegas, NV 89193-8518

Roger Jacobson

Desert Research Institute

Water Resources Center

P.O. Box 19040

Las Vegas, NV 89132-0040

Marjory Jones

Desert Research Institute

Water Resources Center

P.O. Box 60220

Reno, NV 89506-0220

Jim Kannard

Bechtel Nevada Corporation

P.O. Box 98521

Las Vegas, NV 89193-8521

Randy Laczniak

U.S. Geological Survey

Water Resources Division

6770 S. Paradise Rd.

Las Vegas, NV 89119

Paul Liebendorfer

Division of Environmental Protection

State of Nevada

Capitol Complex

Carson City, NV 89710

Frank Maxwell

Environmental Restoration Division

Nevada Operations Office

U.S. Department of Energy

P.O. Box 98518

Las Vegas, NV 89193-8518 
Charles E. McWilliam, Director

Defense Projects Division

Nevada Operations Office

U.S. Department of Energy

P.O. Box 98518

Las Vegas, NV 89193-8518

Steve Mellington, Director

Environmental Restoration Division

Nevada Operations Office

U.S. Department of Energy

P.O. Box 98518

Las Vegas, NV 89193-8518

Leslie A. Monroe

Environmental Protection Division

Nevada Operations Office

U.S. Department of Energy

P.O. Box 98518

Las Vegas, NV 89193-8518

Peter Sanders

Environmental Restoration Division

Nevada Operations Office

U.S. Department of Energy

P.O. Box 98518

Las Vegas, NV 89193-8518

David K. Smith

Isotopes Sciences Division

Lawrence Livermore National Laboratory

P.O. Box 808. M/S L231

Livermore, CA 94550

Doug Trudeau

U.S. Geological Survey

Water Resources Division

6770 S. Paradise Rd.

Las Vegas, NV 89119

Annie Kelley

State Documents Department

Nevada State Library

Capitol Complex

Carson City, NV 89710
Archives

Getchell Library

University of Nevada, Reno

Beverly Carter

MacKay School of Mines Library

University of Nevada, Reno

Document Section, Library

University of Nevada, Las Vegas

4505 Maryland Parkway

Las Vegas, NV 89154

Library

Desert Research Institute

P.O. Box 60220

Reno, Nevada 89506-0220

Library

IT Corporation

4330 S. Valley View

Suite 114

Las Vegas, NV 89103

ATTN: Toni Miller

Library

Southern Nevada Science Center

Desert Research Institute

P.O. Box 19040

Las Vegas, NV 89132-0040

Technical Information Resource Center

Nevada Operations Office

U.S. Department of Energy

P.O. Box 98518

Las Vegas, NV 89193-8518

Public Reading Facility

Bechtel Nevada Corporation

P.O. Box 98521

Las Vegas, NV 89193-8521

Office of Scientific and Technical Information

U.S. Department of Energy

P.O. Box 62

Oak Ridge, TN 37831-9939 